\title{
Does Trade Openness Reduce Inflation? Empirical Evidence from Pakistan
}

\section{Tahir Mukhtar*}

\begin{abstract}
:
One of the more celebrated propositions found in international trade is the case that trade liberalization is associated with declining prices, so that protectionism is inflationary. In line with this view, Romer (1993) postulates the hypothesis that inflation is lower in small and open economies. The objective of this study is to examine Romer's hypothesis in Pakistan. For this purpose, we have used multivariate cointegration and a vector error correction model. The study covers the period from 1960 to 2007. The empirical findings under the cointegration test show that there is a significant negative long-run relationship between inflation and trade openness, which confirms the existence of Romer's hypothesis in Pakistan.
\end{abstract}

Keywords: Trade openness, inflation, cointegration, vector error correction model, Pakistan.

JEL Classification: C22, F41, O53.

\section{Introduction}

One of the more celebrated propositions found in every international trade text is the case that trade liberalization is associated with declining prices, so that protectionism is inflationary. In today's world, no developing country can afford to isolate itself from the world economy. The benefits of outward-looking policies that help in taking advantage of the possibilities of international trade and capital flows are extensively discussed in the literature. Economic liberalization, globalization, and openness became buzzwords in the 1990s. There has been a distinct shift in favor of greater integration of the world economy. This trend has been toward greater opening up and most developing economies have moved away from the typical closed economy structure.

\footnotetext{
* Assistant Professor, Department of Economics, Fatima Jinnah Women's University, Rawalpindi.
} 
Sustained low inflation has been a stylized fact of the late 1990s and early 2000s, both in advanced and increasingly in emerging markets. Some have argued that these developments could reflect stiffer global competition and the increased weight of developing countries in the global trading system (Rogoff, 2003). The relationship between inflation and openness has been the subject of research, theoretical as well as empirical. However, the literature on the subject is relatively scant. According to the 'new growth theory', openness is likely to affect inflation through its effect on output (Jin, 2000). This link could operate through: (i) increased efficiency, which is likely to reduce costs through changes in the composition of inputs procured domestically and internationally; (ii) better allocation of resources; (iii) increased capacity utilization; and (iv) a rise in foreign investment which could stimulate output growth and ease pressure on prices (Ashra, 2002).

When we review some of the existing empirical studies of the relationship between openness and inflation, we find inconclusive evidence suggesting that greater openness is associated with a lower trend in inflation. Romer (1993) finds that closed economies tend to have higher inflation. He argues that central banks in economies more open to trade find currency fluctuations caused by money surprises more painful and therefore exercise more restraint than their closed economy counterparts. Several studies have tested Romer's argument in different ways and have supported the conventional view of the negative relationship between trade openness and inflation. Thus empirical findings of Lane (1997), Ashra (2002), Sachsida et al. (2003), Yanikkaya (2003), Gruben and Mcleod (2004), Kim and Beladi (2004), Daniels et al. (2005), Razin and Loungani (2005), Aron and Muellbauer (2007), Badinger (2007), Bowdler and Nunziataz (2007) all validate Romer's argument. However, Terra (1998) only marginally supports Romer's argument by claiming that the negative correlation is only evident in severely indebted countries during the 1980s crisis period. Similarly, Batra (2001) argues that tariffs do not necessarily cause inflation, at least in the US. Gruben and Mcleod (2004) show that there does not exist any significant openness-inflation relationship among OECD economies. Kim and Beladi (2004) have estimated a positive relationship between price level and trade openness for some advanced economies, such as the US, Belgium, and Ireland, while for other countries, both developed and developing, their finding is in line with Romer's (1993) argument. Finally, it is interesting to note that Romer (1993) himself finds no significant openness-inflation relationship among OECD economies. 
Most studies of the role of openness have focused on the estimation of cross-country averages of many different levels of economies. However, these studies cannot identify country-specific differences. Little work has been done on the dynamics of the impact of openness on inflation at a country level. The literature on the trade openness-inflation association in Pakistan is scarce. Ashra (2002), Kim and Beladi (2004) and Gruben and Mcleod (2004) have reported evidence of a negative relationship between trade openness and inflation for Pakistan using a panel data framework. However, we have come across only one study on Pakistan that uses time series data. Hanif and Batool (2006) have tested Romer's hypothesis for the Pakistan economy using annual time series data for the period 1973 to 2005. They find that, besides conventional explanatory variables like real gross domestic product (GDP) growth, monetary growth, the interest rate, and wheat support price, openness variables such as the ratio of growth in overall trade to GDP also has a significant negative impact on domestic price growth in Pakistan. However, this study suffers from one serious limitation: it uses a small number of observations (i.e., 32 in all) for carrying out the analysis using the heteroscedasticity and autocorrelation consistent (HAC) standards errors estimation technique. This technique is only valid for large samples and may not be appropriate for small samples (Gujarati, 2003). Thus, in the presence of relatively small data, the study is unable to provide conclusive results. Therefore, there is a need to reexamine the issue using a relatively larger data set and a more sophisticated estimation technique to obtain more reliable findings. This study is an attempt in that direction.

Until the mid-1980s, Pakistan pursued an economic policy that was strongly interventionist. During the late 1980s, Pakistan turned from inward-looking policies toward trade liberalization and export promotion strategies. From the late 1980s onwards, governments changed frequently but all of them liberalized the economy considerably. However, despite making the economy steadily more open, inflation has not been maintained within desirable limits in Pakistan. The objective of the study is to determine the nature of the relationship between inflation and trade openness in Pakistan.

The rest of the study is organized as follows: The theoretical model, sources of data and estimation technique are described in Section 2. Section 3 presents a discussion on the estimated results. Section 4 concludes the study. 


\section{Model, Data and Estimation}

Inflation is a complex process and it is very difficult to construct an empirical model for a country. However, it is possible to find the key variables impacting the inflation process in a country like Pakistan. The most common empirical method of examining the trade opennessinflation relationship has been to employ a single equation model for inflation, treating trade openness as an exogenous variable among others. Solomon and de Wet (2004) use a four-variable single equation model where the budget deficit (BD), GDP, and the exchange rate (ER) are treated as exogenous variables, and inflation (CPI) as an endogenous variable. To this, we add trade openness (TO) as an exogenous variable.

$$
L C P I_{t}=\alpha_{1}+\alpha_{2} L B D_{t}+\alpha_{3} L E R_{t}+\alpha_{4} T O_{t}+\alpha_{5} L G D P_{t}+u_{t}
$$

where $L C P I_{t}, L B D_{t}, L E R_{t}, T O_{t}$ and $L G D P_{t}$ represent the consumer price index (CPI), budget deficit, exchange rate, trade openness, and GDP, respectively, expressed in natural logarithms except for trade openness at time t. $u$ is a stochastic error term.

Now we present a brief discussion on the expected relationship between inflation and the explanatory variables in the above model. The influence of the budget deficit on inflation is positive: the higher the budget deficit, the greater the rate of inflation. The budget deficit affects inflation only if it is monetized, thus increasing the monetary base of the economy. According to Friedman's theory of money, inflation is a monetary phenomenon. Accordingly, if the budget deficit is monetized, it increases the money supply thereby increasing the price level. When the budget deficit is monetized, an extremely high correlation exists between the budget deficit and money supply. The problem of multicollinearity and reducibility precludes one from using both money supply and the budget deficit as explanatory variables in the regression analysis. Therefore, in order to estimate the effect of the budget deficit on inflation, the budget deficit is used as an explanatory variable instead of money supply. The exchange rate has a deterministic effect on the level of prices in underdeveloped economies. In countries like Pakistan, an exchange rate depreciation (appreciation) could increase (decrease) the price of imported commodities. Pakistan's markets are based significantly on imported commodities, implying that a depreciation of the exchange rate would be rapidly reflected in an increase in the price of the consumer's basket of commodities. 
The expected impact of trade openness on inflation is negative because the direct and indirect price effects of cheaper imports of finished goods and intermediate inputs may net out to a decline in the overall price level. Additionally, opening up an economy to the rest of the world may alter the incentives to which central banks respond in determining a country's long-run inflation rate. Finally, openness could also lead indirectly to lower inflation by fostering faster domestic productivity growth as a result of increased competition. Because trade enables countries to specialize in activities in which they have a comparative advantage, sectors in which countries are relatively inefficient shrink, while sectors in which countries have a comparative advantage expand. Faster productivity growth allows firms to pay higher wages without necessarily passing these costs on in the form of higher prices. The fourth important explanatory variable is the level of GDP, which has an expected negative impact on the inflation rate as the availability of goods and services in the economy eases pressure on the domestic price growth. ${ }^{1}$

The time span covered in this study is from 1960 to 2007; we have used annual time series data. The inflation rate is proxied using the logarithm of the composite CPI. The control of inflation, measured as the annual growth rate of this variable, is the main goal of monetary policy and the State Bank of Pakistan (SBP) sets a target. In practice, the most commonly used measure of openness is the sum of imports and exports divided by GDP. This ratio generally reveals the degree of a country's openness to world trade: The more open a domestic economy, the less the restriction in world trade, and the higher the trade share in GDP. No doubt, there are various other possible measures that could be used as a proxy for openness but it is difficult to obtain long historical time series for most of these (Ashra, 2002). Thus, we restrict ourselves to the trade-toGDP ratio, which indicates the overall openness of the economy. Other variables included in the analysis are the government budget deficit (BD), exchange rate (ER), and GDP. The data, seasonally unadjusted and expressed in nominal terms, has been obtained from various issues of the Pakistan Economic Survey and the IMF's International Financial Statistics.

\subsection{Unit Root Test}

Since macroeconomic time series data is usually nonstationary (Nelson \& Plosser, 1982) and thus conducive to spurious regression, we test for the stationarity of a time series at the outset of our cointegration

\footnotetext{
${ }^{1}$ There is a vast literature on inflation and growth. I did not go into the details of it.
} 
analysis. Testing for a unit root is an active research area, and several testing procedures have been developed over the years. Many of these tests are designed to overcome the difficulties encountered in practice. In this regard, the present study uses the augmented Dickey-Fuller (ADF) test, which is based on the t-ratio of the parameter in the following regression.

$$
\Delta X_{t}=\kappa+\phi t+\Theta_{i} X_{t-i}+\sum_{i=1}^{n} \varphi_{i} \Delta X_{t-i}+\varepsilon_{t}
$$

where $X$ is the variable under consideration, $\Delta$ is the first difference operator, $t$ captures any time trend, $\varepsilon_{t}$ is a random error, and $n$ is the maximum lag length. The optimal lag length is identified to ensure that the error term remains white noise, while $\kappa, \phi, \Theta$ and $\varphi$ are the parameters to be estimated. If we cannot reject the null hypothesis $\Theta=0$, we can conclude that the series under consideration has a unit root and is therefore nonstationary.

However, the ADF unit root test is known to lose power dramatically against stationary alternatives with a low order MA process: a characterization that fits well with a number of macroeconomic time series. Consequently, along the lines of the ADF test, a more powerful variant is the Dicky-Fuller generalized least square (DFGLS) de-trending test proposed by Elliott, Rothenberg and Stock (1996). This test is similar to an ADF test, but has the best overall performance in terms of small sample size and power, dominating the ordinary Dickey-Fuller test. Therefore, to check the stationary of variables, we have also used the DFGLS test.

It is essential at the onset of cointegration analysis that we solve the problem of optimal lag length because multivariate cointegration analysis, which we are going to conduct in this study, is very sensitive to lag length selection. The two most commonly used lag length selection criteria are the Akaike information criterion (AIC) and the Schwarz Bayesian criterion (SBC).

\subsection{Cointegration Test}

The econometric framework used for analysis in this study is the Johansen (1998) and Johansen and Juselius (1990) maximum likelihood cointegration technique, which tests both the existence and number of cointegration vectors. This multivariate cointegration test can be expressed as: 


$$
Z_{t}=K_{1} Z_{t-1}+K_{2} Z_{t-2}+\ldots . .+K_{k-1} Z_{t-k}+\mu+v_{t}
$$

where

$Z_{t}=(C P I, B D, E R, T O, G D P)$ i.e., a $5 \times 1$ vector of variables that are integrated of order one [i.e. I (1)], CPI, BD, ER, TO and GDP are the price level, budget deficit, exchange rate, trade openness, and GDP, respectively,

$$
\begin{aligned}
& \mu=\text { a vector of constant and } \\
& v_{t}=\text { a vector of normally and independently distributed error term. }
\end{aligned}
$$

Equation (3) can be reformulated in a vector error correction model (VECM) as follows:

$$
\Delta \mathrm{Z}_{t}=\Gamma_{1} \Delta \mathrm{Z}_{t-1}+\Gamma_{2} \Delta \mathrm{Z}_{t-2}+\cdots \cdots+\Gamma_{k-1} \Delta \mathrm{Z}_{t-k-1}+\Pi \mathrm{Z}_{t-1}+\mu+v_{t}
$$

where, $\Gamma_{i}=\left(I-A_{1}-A_{2} \ldots . .-A_{i}\right), i=1,2,3 \ldots . . k-1$ and $\Pi=-\left(I-A_{1}\right.$ $\left.-A_{2}-A_{3} \ldots . .-A_{k}\right)$. The coefficient matrix $\Pi$ provides information about the long-run relationships among the variables in the data. $\Pi$ can be factored into $\alpha \beta^{\prime}$ where $\alpha$ will include the speed of adjustment to the equilibrium coefficients while the $\beta^{\prime}$ will be the long-run matrix of coefficients. The presence of $r$ cointegrating vectors between the elements of $Z$ implies that $\Pi$ is of the rank $r,(0<r<5)$. To determine the number of cointegrating vectors, Johansen developed two likelihood ratio tests: the trace test $\left(\lambda_{\text {trace }}\right)$ and the maximum eigenvalue test $\left(\lambda_{\max }\right)$. If there is any divergence of results between these two tests, it is advisable to rely on the evidence based on the $\lambda_{\max }$ test because it is more reliable in small samples (see Dutta \& Ahmed, 1997, and Odhiambo, 2005).

\section{Results and Discussion}

The first step in cointegration analysis is to test the unit roots in each variable. ${ }^{2}$ To this end, we apply the ADF stationary test to LCPI, LBD, LER, TO and LGDP. ${ }^{3}$ From the results of the ADF test presented in

\footnotetext{
${ }^{2}$ Since the cointegration methodology involves finding a stationary linear combination of a set of variables, which are themselves nonstationary, a precondition for cointegration is that all variables should be nonstationary.

${ }^{3}$ All the variables are logarithmic except trade openness.
} 
Table 1, it is evident that all the time series used in the study are stationary at first difference as expected. This implies that they are integrated of the order one, i.e., I(1). Similar results for all the macroeconomic variables are found under the DFGLS test. ${ }^{4}$ To obtain the optimal lag length for cointegration analysis, we use two criteria, namely the AIC and the SBC. The SBC has a suggested a lag length of 1 as optimal, while the AIC indicates 3 as an optimal lag length (see Table A2 in the appendix). However, we have selected optimal lag length 1 as suggested by the SBC because when we use the lag length 3 for cointegration analysis, we find no cointegrating vector under both trace and maximum eigen statistics, while with lag length 1 , we obtain one cointegrating vector under both these statistics.

Table-1: Augmented Dickey Fuller (ADF) Unit Root Tests

\begin{tabular}{|c|c|c|c|c|c|c|c|}
\hline \multirow[b]{2}{*}{ Variables } & \multirow[b]{2}{*}{ Level } & \multirow{2}{*}{$\begin{array}{c}\text { First } \\
\text { Difference }\end{array}$} & \multicolumn{3}{|c|}{$\begin{array}{c}\text { Mackinnon Critical } \\
\text { Values for Rejection of } \\
\text { Hypothesis of a Unit Root }\end{array}$} & \multirow[b]{2}{*}{ Decision } & \multirow[b]{2}{*}{$\begin{array}{c}\text { Order of } \\
\text { Integration }\end{array}$} \\
\hline & & & $1 \%$ & $5 \%$ & $10 \%$ & & \\
\hline $\mathrm{LCPI}$ & 6.791 & -1.621 & -2.58 & -1.94 & -1.62 & $\begin{array}{l}\text { Nonstationary at } \\
\text { level but stationary } \\
\text { at first difference }\end{array}$ & $I(1)$ \\
\hline LBD & -0.051 & -10.439 & -2.58 & -1.94 & -1.62 & $\begin{array}{l}\text { Nonstationary at } \\
\text { level but stationary } \\
\text { at first difference }\end{array}$ & $I(1)$ \\
\hline LEX & 1.283 & -7.089 & -2.58 & -1.94 & -1.62 & $\begin{array}{l}\text { Nonstationary at } \\
\text { level but stationary } \\
\text { at first difference }\end{array}$ & $I(1)$ \\
\hline TO & -2.108 & -3.744 & -2.58 & -1.94 & -1.62 & $\begin{array}{l}\text { Nonstationary at } \\
\text { level but stationary } \\
\text { at first difference }\end{array}$ & $I(1)$ \\
\hline LGDP & 4.909 & -4.476 & -2.58 & -1.94 & -1.62 & $\begin{array}{l}\text { Nonstationary at } \\
\text { level but stationary } \\
\text { at first difference }\end{array}$ & $I(1)$ \\
\hline
\end{tabular}

The cointegration relationship among CPI, BD, ER, TO, and GDP has been investigated assuming a linear trend in the data, and both an intercept and a trend in the cointegrating equation using the Johansen technique. Table 2 reports our cointegration test results based on Johansen's maximum likelihood method. Both the trace statistic $\left(\lambda_{\text {trace }}\right)$

\footnotetext{
${ }^{4}$ See Table A1 in the appendix.
} 
and maximal eigenvalue $\left(\lambda_{\max }\right)$ statistic indicate that there is at least one cointegrating vector among the five time series. We can reject the null hypothesis of no cointegrating vector in favor of one cointegrating vector under both test statistics at a 5 percent level of significance. We cannot reject the null hypothesis of at most one cointegrating vector against the alternative hypothesis of two cointegrating vectors for both the trace and max-eigen test statistics. Consequently, we can conclude that there is only one cointegrating relationship among CPI, BD, ER, TO and GDP. This implies that the price level, budget deficit, exchange rate, trade openness, and GDP establish a long-run relationship in Pakistan.

Table-2.Cointegration Test Based on Johansen's Maximum Likelihood Method

\begin{tabular}{|c|c|c|c|c|c|}
\hline \multirow{2}{*}{$\begin{array}{l}\text { Null } \\
\text { Hypothesis }\end{array}$} & \multirow{2}{*}{$\begin{array}{l}\text { Alternative } \\
\text { Hypothesis }\end{array}$} & & & \multicolumn{2}{|c|}{ Critical Values } \\
\hline & & & & $95 \%$ & P-values* \\
\hline $\begin{array}{l}\lambda_{\text {trace }} \text { rank } \\
\text { tests }\end{array}$ & & $\begin{array}{l}\text { Eigen } \\
\text { values }\end{array}$ & $\begin{array}{c}\lambda_{\text {trace }} \text { rank } \\
\text { value }\end{array}$ & & \\
\hline$H_{0}: r=0$ & $H_{1}: r=1$ & 0.682 & $103.313^{* * *}$ & 76.973 & 0.0001 \\
\hline$H_{0}: r=1$ & $H_{1}: r=2$ & 0.392 & 51.72 & 54.079 & 0.08 \\
\hline$H_{0}: r=2$ & $H_{1}: r=3$ & 0.263 & 29.362 & 35.193 & 0.186 \\
\hline$\lambda_{\max }$ rank tests & & & $\lambda_{\max }$ rank & & \\
\hline$H_{0}: r=0$ & $H_{1}: r>0$ & 0.682 & $51.592^{* * *}$ & 34.806 & 0.0002 \\
\hline$H_{0}: r \leq 1$ & $H_{1}: r>1$ & 0.392 & 22.358 & 28.588 & 0.254 \\
\hline$H_{0}: r \leq 2$ & $H_{1}: r>2$ & 0.263 & 13.729 & 22.23 & 0.487 \\
\hline
\end{tabular}

Normalized Cointegrating Equation:

$\mathrm{LCPI}=1.987+0.102^{*} \mathrm{LBD}+0.388^{*} \mathrm{LEX}-0.681^{*} \mathrm{TO}-0.421^{*} \mathrm{LGDP}$

$(2.031)^{* *}(13.116)^{* * *}(2.514)^{* *}(-4.732)^{* * *}(-4.236)^{* * *}$

***denotes rejection of the null hypothesis at the 1 percent significance level.

** denotes rejection of the null hypothesis at the 5 percent significance level.

* MacKinnon-Haug-Michelis (1999) p-values.

Trace test indicates 1 cointegrating equation at 1 percent significance level.

Max-eigenvalue test indicates 1 cointegrating equation at 1 percent significance level.

The cointegrating equation, which is given at the bottom of Table 2 , is normalized for LCPI to obtain meanings from the coefficients. All the 
explanatory variables significantly affect the CPI. The coefficients of all the logarithmic variables may be interpreted in terms of elasticity. Thus, we can state that 1 percent increase in BD is associated with a 0.10 percent increase in CPI in Pakistan. Since the coefficient estimate for the budget deficit is significant, it implies that there is a significant long-run relationship between inflation and the budget deficit. This result is in accordance with the findings of Chaudhary and Ahmad (1995) and Agha and Khan (2006) that the budget deficit ultimately induces inflation in Pakistan. There exists a positive relationship between LCPI and LEX in such a way that a 1 percent increase in the nominal exchange rate results in a 0.38 percent increase in the inflation rate in the country. This implies that it is not advisable for policymakers to implement a flexible exchange rate system because that could lead to a major depreciation that would create inflationary problems. The coefficient of trade openness carries a negative sign, which shows that a 1 unit increase in trade openness brings about a 0.68 percent decrease in the inflation rate. This finding is consistent with the empirical findings of Romer (1993), Kim and Beladi (2004), Ashra (2002) and Gruben and Mcleod (2004), among others. Furthermore, it validates the results of Hanif and Batool (2006) that openness has a significant negative impact on the domestic price growth in Pakistan. This finding confirms the existence of Romer's hypothesis in Pakistan: inflation is lower in small and open economies. Furthermore, it indicates that the traditional closed economy explanation for the inflationary process remains valid, and adding the openness variable to the analysis is an important component to the empirical analysis of these macroeconomic phenomena. Finally, there is a significant negative relationship between the CPI and GDP such that a 0.42 percent decrease in the CPI is associated with a 1 percent increase in GDP.

A principal feature of cointegrated variables is that their time paths are influenced by the extent of any deviation from the long-run equilibrium (Anders, 2004). The error correction term (ECT) represents the percentage of correction to any deviation in the long-run equilibrium price in a single period and also represents how fast the deviations in the long-run equilibrium are corrected. The coefficient of the ECT of inflation variable carries the correct sign (negative) and statistically significant at a 10 percent level with the speed of convergence to equilibrium of 27 percent (Table 3). This means that, whenever there is any disturbance in the system in the long run, in every short-run period, a 27 percent correction to disequilibrium will take place. The overall restoration to equilibrium will happen in almost four years. This indicates the stability of the model. The coefficients of the ECTs of trade openness, exchange 
rate, and GDP are statistically significant but they carry a positive sign. This means that, in case of any disturbance, divergence from the equilibrium path will take place and the whole system cannot be brought to equilibrium position in each case. The coefficient of the ECT of the budget deficit is not only insignificant but also carries the incorrect sign, i.e., positive. The insignificance of the ECT component for this variable indicates that this variable is weakly exogenous to the model. The diagnostic tests involve $\chi^{2}$ tests for the hypothesis that there is no serial correlation, that the residual follows a normal distribution, that there is no heteroscedasticity, and lastly that there is no autoregressive conditional heteroscedasticity. In all equations, the diagnostics suggest that the residuals are Gaussian as the Johansen method presupposes.

Table-3.Summary Results from VECMs and Diagnostic Tests

\begin{tabular}{|c|c|c|c|c|c|}
\hline & $\triangle L(C P I)$ & $\Delta L(B D)$ & $\Delta L(E X)$ & $\Delta L(T O)$ & $\Delta L(G D P)$ \\
\hline Constant & $\begin{array}{c}0.026 \\
(2.737)^{* * * *}\end{array}$ & $\begin{array}{c}0.177 \\
(0.880)\end{array}$ & $\begin{array}{c}0.121 \\
(3.667)^{* *}\end{array}$ & $\begin{array}{c}0.043 \\
(1.576)^{* *}\end{array}$ & $\begin{array}{c}0.038 \\
(1.857)^{* *}\end{array}$ \\
\hline $\mathrm{ECT}(-1)$ & $\begin{array}{l}-0.275 \\
(1.898)^{*}\end{array}$ & $\begin{array}{c}1.761 \\
(1.683)\end{array}$ & $\begin{array}{c}0.417 \\
(2.422)^{* *}\end{array}$ & $\begin{array}{c}0.853 \\
(5.887)^{* * *}\end{array}$ & $\begin{array}{c}0.102 \\
(0.952)\end{array}$ \\
\hline$R^{2}$ & 0.684 & 0.277 & 0.548 & 0.604 & 0.391 \\
\hline Adjusted $R^{2}$ & 0.633 & 0.163 & 0.477 & 0.543 & 0.354 \\
\hline S.E. of Regression & 0.032 & 0.669 & 0.111 & 0.093 & 0.068 \\
\hline Diagnostic Tests & \multicolumn{5}{|c|}{$\chi^{2}(p$ values are in the parenthesis $)$} \\
\hline $\begin{array}{l}\text { Serial Correlation } \\
\text { (Breusch-Godfrey } \\
\text { serial LM) }\end{array}$ & $1.24(0.441)$ & $0.791(0.557)$ & $1.31(0.262)$ & $2.15(0.156)$ & $1.34(0.238)$ \\
\hline $\begin{array}{l}\text { Heteroscedasticity } \\
\text { (White } \\
\text { Heteroskedasticity } \\
\text { Test) }\end{array}$ & $0.04(0.982)$ & $1.33(0.268)$ & $1.351(0.252)$ & $2.27(0.157)$ & $0.084(0.897)$ \\
\hline $\begin{array}{l}\text { Normality } \\
\text { (Jorque-Bera) }\end{array}$ & $0.411(0.644)$ & $0.774(0.361)$ & $0.524(0.391)$ & $2.3(0.194)$ & $0.46(0.78)$ \\
\hline $\begin{array}{l}\text { AR.Cond. } \\
\text { Heteroscedasticity } \\
\text { (ARCH LM Test) }\end{array}$ & $0.007(0.938)$ & $1.344(0.261)$ & $0.004(0.964)$ & $1.247(0.285)$ & $1.086(0.337)$ \\
\hline
\end{tabular}

Note: $\mathrm{t}$-values given in parenthesis with, ${ }^{* * *}, * * *$, indicate significance at 1 percent, 5 percent and 10 percent probability level respectively. 


\section{Conclusion}

Inflation has always been a concern for policymakers as it creates uncertainty in the economy that can adversely affect economic growth. Maintaining noninflationary stable economic growth has been at the core of macroeconomic policies in Pakistan as in many other developing countries. The concern with inflation stems not only from the need to maintain overall macroeconomic stability, but also from the fact that inflation hurts the poor in particular as they do not possess effective inflation hedges.

An important debate has centered on the effects of openness (in the trade-flow sense) on inflation. Theoretically, two alternative views have been espoused concerning the issue. One of these states that openness causes a slower rate of inflation, while the other states that openness causes a faster rate of inflation. Many empirical studies have been performed to test these hypotheses. However, there is inconclusive evidence in support of these two views.

The main objective of this paper was to apply the cointegration approach in order to reexamine whether the hypothesis proposed by Romer (1993), that there is a negative relationship between inflation and trade openness, holds for Pakistan. The study has used annual observations for the period 1960 to 2007. The results obtained corroborate Romer's proposition. This study further supports the results obtained by Romer (1993), demonstrating that there is a negative relationship between openness and inflation. Thus, whatever its cause, that greater openness to trade is associated with lower inflation should provide some comfort to those who fear that trade liberalization and flexible exchange rates will increase macroeconomic instability in Pakistan. 


\section{References}

Agha, A.I., and Khan, M.S. (2006). An Empirical Analysis of Fiscal Imbalances and Inflation in Pakistan. SBP Research Bulletin, 2(2): 343-362.

Aron, J., and John, M. (2007). Inflation Dynamics and Trade Openness: With an Application to South Africa. Centre for the Study of African Economies Working Paper Series. Working Paper 270.

Ashra, S. (2002). Inflation and Openness: A Case Study of Selected Developing Economies. Working Paper 84. Indian Council of Research on International Economic Relations (ICRIER).

Badinger, H. (2007). Globalization, the Output-Inflation Tradeoff, and Inflation. FIW Working Paper 10, Austria.

Batra, R. (2001). Are Tariffs Inflationary? Review of International Economics, 9, 373-82.

Bowdler, C., and Nunziataz, L. (2007). Trade Union Density and Inflation Performance: Evidence from OECD Panel Data. Economica, 74 (293), 135-59.

Chaudhary, M.A., and Ahmad, N. (1995). Money Supply, Deficit and Inflation in Pakistan. Pakistan Development Review, 34, 945-56.

Daniels, J., Nourzad, F., and Van Hoose, D. (2005). Openness, Central Bank Independence, and the Sacrifice Ratio. Journal of Money, Credit, and Banking, 37, 371-379.

Dutta, D., and Ahmed, N. (1997). An Aggregate Import Demand Function for Bangladesh: A Cointegration Approach. Working Paper. University of Sydney.

Elliot, G., Rothenberg, T.J., and Stock, J.H. (1996). Efficient Tests for an Autoregressive Unit Root. Econometrica, 64, 813-36.

Enders, W. (1995). Applied Econometric Time Series. New York: John Wiley.

Engle, R.F., and Granger, C.W.J. (1987). Cointegration and Error Correction Representation, Estimation and Testing. Econometrica, $55,251-76$. 
Government of Pakistan. (2008). Pakistan Economic Survey. Islamabad: Economic Advisory Wing, Finance Division.

Gruben, W.C., and McLeod, D. (2004). The Openness-Inflation Puzzle Revisited. Applied Economics Letters, 11, 465-468.

Gujarati, D. (2003). Basic Econometrics. New York: McGraw-Hill.

Jin, C.J. (2006). Can Openness be an Engine of Sustained High Growth Rates and Inflation? Evidence from Japan and Korea. International Review of Economics and Finance, 15, 228-240.

Johansen, S. (1988). Statistical Analysis of Cointegration Vectors. Journal of Economic Dynamics and Control, 12, 231-254.

Johansen, S., and Juselius, K. (1990). The Maximum Likelihood Estimation and Inference on Cointegration with Application to Demand for Money. Oxford Bulletin of Economics and Statistics, 52, 169-210.

Kim, M., and Beladi, H. (2005). Is Free Trade Deflationary? Economic Letters, 89, 343-349.

Lane, P.R. (1997). Inflation in Open Economies. Journal of International Economics, 42, 327-347.

Masih, A.M.M., and Masih, R. (1997). On the Temporal Causal Relationship between energy Consumption, Real Income, and Prices: Some New Evidence from Asian Energy Dependent NICs based on a Multivariate Cointegration/Vector Error Correction Approach. Journal of Policy Modeling 19 (4), 417-440.

Nelson, C., and Plosser, C. (1982). Trends and Random Walks in Macroeconomic Time Series: Some Evidence and Implications. Journal of Monetary Economics, 10, 130-162.

Odhiambo, N. M. (2005). Financial Liberalization and Financial Deepening: Evidence from Three Sub-Saharan African Countries. African Review of Money, Finance and Banking (Savings and Development Supplement), 5-23.

Razin, A., and Loungani, P. (2005). Globalization and Equilibrium Output-Inflation Trade-Offs. NBER International Seminar on Macroeconomics (September). 
Rogoff, K. (2003). Globalization and the Global Disinflation. Paper presented to the Federal Reserve Bank of Kansas, Jackson Hole Conference.

Romer D. (1993). Openness and Inflation: Theory and Evidence. Quarterly Journal of Economics, 108 (4), 869-903.

Sachsida, A., Galrao, F., and Loureiro, P.R.A. (2003). Does Greater Trade Openness Reduce Inflation? Further Evidence Using Panel Data Techniques. Economic Letters, 81, 315-319.

Solomon, M., and de Wet, W.A. (2004). The Effect of a Budget Deficit on Inflation: The Case of Tanzania. South African Journal of Economic and Management Sciences, 7 (1), 100-116.

Terra, C.T. (1998). Openness and Inflation: A New Assessment. Quarterly Journal of Economics, (113), 641-648.

Yanikkaya H. (2003). Trade Openness and Economic Growth: A CrossCountry Empirical Investigation. Journal of Development Economics, $72,57-89$. 


\section{Appendix}

\section{Table-A1: DF-GLS Unit Root Tests}

\begin{tabular}{|c|c|c|c|c|c|c|c|}
\hline \multirow[b]{2}{*}{ Variables } & \multirow[b]{2}{*}{ Level } & \multirow{2}{*}{$\begin{array}{c}\text { First } \\
\text { Difference }\end{array}$} & \multicolumn{3}{|c|}{$\begin{array}{c}\text { Mackinnon Critical } \\
\text { Values for Rejection of } \\
\text { Hypothesis of a Unit Root }\end{array}$} & \multirow[b]{2}{*}{ Decision } & \multirow[b]{2}{*}{$\begin{array}{c}\text { Order of } \\
\text { Integration }\end{array}$} \\
\hline & & & $1 \%$ & $5 \%$ & $10 \%$ & & \\
\hline$\overline{\mathrm{LCPI}}$ & -0.438 & -4.935 & -3.77 & -3.19 & -2.89 & $\begin{array}{l}\text { Nonstationary at } \\
\text { level but stationary } \\
\text { at first difference }\end{array}$ & $I(1)$ \\
\hline TO & -1.955 & -4.959 & -3.77 & -3.19 & -2.89 & $\begin{array}{l}\text { Nonstationary at } \\
\text { level but stationary } \\
\text { at first difference }\end{array}$ & $I(1)$ \\
\hline LRGDP & -3.497 & -6.375 & -3.77 & -3.19 & -2.89 & $\begin{array}{l}\text { Nonstationary at } \\
\text { level but stationary } \\
\text { at first difference }\end{array}$ & $I(1)$ \\
\hline LEX & -2.151 & -7.436 & -3.77 & -3.19 & -2.89 & $\begin{array}{l}\text { Nonstationary at } \\
\text { level but stationary } \\
\text { at first difference }\end{array}$ & $I(1)$ \\
\hline LBD & -2.101 & -7.523 & -3.77 & -3.19 & -2.89 & $\begin{array}{l}\text { Nonstationary at } \\
\text { level but stationary } \\
\text { at first difference }\end{array}$ & $I(1)$ \\
\hline
\end{tabular}

Table-A2: Lag Order Selection

\begin{tabular}{ccc}
\hline Lag & AIC & SC \\
\hline 0 & 1.776864 & 1.981655 \\
1 & -7.158782 & $-5.930038^{*}$ \\
2 & -7.945100 & -5.692402 \\
3 & $-8.880952^{*}$ & -5.604301 \\
4 & -8.698020 & -4.397415 \\
\hline
\end{tabular}

* indicates lag order selected by the criterion AIC: Akaike information criterion SC: Schwarz information criterion 